Canadian Science Publishing
nichenem

Canadian Journal of Microbiology Revue canadienne de de microbiologie

\title{
Damage to Trichothecium roseum caused by sodium silicate is independent from $\mathrm{pH}$
}

\begin{tabular}{|r|l|}
\hline Journal: & Canadian Journal of Microbiology \\
\hline Manuscript ID & cjm-2015-0657.R1 \\
\hline Manuscript Type: & Article \\
\hline Date Submitted by the Author: & 09-Nov-2015 \\
\hline Complete List of Authors: & $\begin{array}{l}\text { Niu, Lili; Gansu Agricultural University } \\
\text { Bi, Yang; Gansu Agricultural University } \\
\text { Bai, Xiaodong; Gansu Agricultural University } \\
\text { Zhang, Shenggui; Gansu Agricultural University } \\
\text { Xue, Huali; GanSu Agricultural University, College of Food Science and } \\
\text { Engineering } \\
\text { Li, Yongcai; Gansu Agricultural University } \\
\text { Wang, Yi; Gansu Agricultural University } \\
\text { Alejandro, Calderón-Urrea; California State University }\end{array}$ \\
\hline Keyword: & \begin{tabular}{l} 
Sodium silicate, Inhibition, Pathogenicity, Conidia ultrastructure \\
\hline
\end{tabular} \\
\hline
\end{tabular}

SCHOLARONE $^{\text {IM }}$

Manuscripts 
1 Damage to Trichothecium roseum caused by sodium silicate is independent from $\mathrm{pH}$

3 Niu Li-lii ${ }^{1,2}$, Bi Yang ${ }^{1}$, Bai Xiao-dong ${ }^{1}$, Zhang Sheng-gui ${ }^{1}$, Xue Hua-li ${ }^{1}$, Li Yong-cai,

4 (1)

\section{4} 5

\section{6} 7 9 0 21

$$
\text { Wang } \mathrm{Yi}^{1} \text {, and Alejandro Calderón-Urrea }{ }^{3}
$$

1 College of Food Science and Engineering, Gansu Agricultural University, Lanzhou,

$$
\text { 730070, P.R.China }
$$

2 College of Grassland Sciences and Engineering, Gansu Agricultural University, Lanzhou,

$$
\text { 730070, P.R.China }
$$

3 Department of Biology, California State University, Fresno, Fresno CA 93711,

$$
\text { U.S.A. }
$$

12

3
8

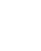


22 ABSTRACT: Trichothecium roseum is one of the most important postharvest pathogens in arid and

semi-arid regions. Sodium silicate $(\mathrm{NaSi})$ and environmental $\mathrm{pH}$ have significant inhibitory effects on fungal growth. However, no study has addressed the relationship of the combined $\mathrm{NaSi} / \mathrm{pH}$ effects on T.roseum. In this work, we showed that spore germination, germ tube elongation and mycelial growth of $T$. roseum were significantly inhibited by various $\mathrm{NaSi}$ concentrations, which had correspondingly increasing pHs. Furthermore, these NaSi solutions showed a much higher effect than $\mathrm{pH}$ treatments alone. The pathogenicity of NaSi-treated conidia on a model assay (conidia inoculated apple fruit) was dramatically reduced while no changes of pathogenicity were evident in the corresponding $\mathrm{pH}$ (various $\mathrm{NaOH}$ solutions) treatments. Fluorescent microscopy, using propidium iodide staining, showed damage of the plasma membranes of $T$. roseum conidia treated with both $\mathrm{NaSi}$ and $\mathrm{NaOH}$, although the damage was more severe with $\mathrm{NaSi}$. Leakage of proteins and sugars were significantly higher in NaSi-treated and $\mathrm{NaOH}$-treated conidia when compared to untreated controls. In addition, serious damage was observed in the conidia exposed to NaSi for longer exposure periods of time. Ultrastructural observations showed that treatment with either $\mathrm{NaSi}$ or $\mathrm{NaOH}$ caused a plasmolysis state and disorganized organelles. Taken together the results show that NaSi has inhibitory effects on T. roseum and that inherent higher $\mathrm{pH}$ of $\mathrm{NaSi}$ solutions of higher concentrations simply act as an enhancer of the inhibitory effects of $\mathrm{NaSi}$.

KEY WORDS: Sodium silicate, Inhibition, Pathogenicity, Conidia ultrastructure 


\section{Introduction}

Trichothecium roseum is an important postharvest pathogen, especially causing core rot of apples (Hu et al. 1995) and pink rot of muskmelons (Bi et al. 2003; Huang et al. 2000). Moreover, the pathogen has been isolated from many fruits such as pears (Sommer et al. 2002), grapes (Serra et al. 2005), and stone fruits (Hong and Michailides 1997). Besides economic losses, the pathogen also possesses a strong ability to produce trichothecenes, which are mycotoxins harmful to humans and animals (Tang et al. 2014; Ueno 1980). Current management to control the diseases caused by $T$. roseum still relies heavily on synthetic chemical fungicides, such as iprodione and azoxystrobin (Bi et al. 2005). However, the increase concerns of the impacts of fungicides on human health and the environment as well as resistance development has prompted the search to develop alternatives to the use of fungicides (Tripathi and Dubey 2004).

Reports indicated that the application of soluble silicon was effective in controlling fungal diseases such as powdery mildews, root rots, and rice blast (Fauteux et al. 2006; Ishiguro 2001; Liang et al. 2005; Moscoso-Ramírez and Palou 2014), as well as postharvest diseases such as green mold of citrus, pink rot of muskmelons, and rots of Hami melons (Bi et al. 2006; Guo et al. 2007; Li et al. 2009b; Liu et al. 2010). The mechanisms of disease control by soluble silicon mainly attributes to the direct inhibition of the growth of the pathogens (Bi et al. 2006; Li et al. 2009b; Qin and Tian 2005), and by induced host resistance (Chérif et al. 1992; Rémus-Borel et al. 2005). Similarly sodium silicate (NaSi) has been generally recognized as safe by the Food and Drug Administration (FDA) of the United States (21CFR 182.90 and 21CFR 182.1711). NaSi has been shown to induce broad-spectrum antimicrobial properties against postharvest pathogens including Penicillium digitatum (Liu et al. 2010), Fusarium sulphureum (Li et al. 2009b), Alternaria alternata, F. semitectum, and T.roseum (Bi et al. 2006).

However, the specific inhibitory mechanisms of NaSi remains unknown. Liu et al. (2010) suggested NaSi could damage the plasma membrane of P.digitatum spores and increase the leakage of proteins and sugars from mycelia. Since solutions of NaSi are inherently alkaline, an increase in $\mathrm{pH}$ might enhance antifungal activity (Guo et al. 2007; Liu et al. 2010). In fact, it was reported that for $P$. expansum spore germination was inhibited, the content of soluble protein in spores was decreased, and the levels of aggregated proteins increased under pH stress ( $\mathrm{Li}$ et al. 2009a). To our knowledge, little 
73 information concerning the relationship between inhibition effects of $\mathrm{NaSi}$ and corresponding $\mathrm{pH}$ is 74 available.

75 In an attempt to study the relationship between NaSi and $\mathrm{pH}$ during pathogenicity of T. roseum 76 conidia on an apple fruit model assay, we quantified the conidial germination and mycelial growth, 77 after treatment with $\mathrm{NaSi}$ and corresponding $\mathrm{pH}$. Membrane integrity and permeability, as well as 78 ultrastructural alterations in conidia were also observed.

\section{Materials and methods}

\section{Pathogen, fruits and chemicals}

An isolate of T.roseum, the pathogen of core rot of apple, was provided by the Institute of Plant Protection, Gansu Academy of Agricultural Sciences, China. Prior to experimentation, the isolate was inoculated into apple fruit and re-isolated onto PDA potato dextrose agar (PDA) (Oxoid, UK) at $28^{\circ} \mathrm{C}$. A conidial suspension was obtained from 10-day-old PDA cultures by flooding the surface of the culture with sterile distilled water containing $0.05 \%(\mathrm{v} / \mathrm{v})$ Tween-80. The conidial suspension was filtered through four layers of sterile cheesecloth and the concentration was adjusted with the aid of a hemocytometer prior to use.

Fruit of apple cv. Delicious was harvested at commercial maturity from Tiaoshan Farm, in Jingtai County of Gansu province, China, on September 23, 2012. The fruit was packed individually, placed in a corrugated box ( 80 apples/box) and transported to the laboratory within $24 \mathrm{~h}$. Apples of the same size and without physical injuries or visible infection were disinfected by immersion in $2 \%(\mathrm{v} / \mathrm{v})$ sodium hypochlorite for $2 \mathrm{~min}$, then rinsed with sterile water, air dried and used for inoculation. Sodium silicate $\left(\mathrm{Na}_{2} \mathrm{SiO}_{3} \cdot 9 \mathrm{H}_{2} \mathrm{O}\right)$, and sodium hydroxide $(\mathrm{NaOH})$ were obtained from Guangfu Fine Chemical Research Institute (Tianjin, China). Propidium iodide (PI) and low gelling temperature agarose were obtained from Sigma-Aldrich (Shanghai, China). Epon 812 was from EMS (Hatfield, Pennsylvania, USA ). Glutaraldehyde, sodium cacodylate, osmium tetroxide, uranyl acetate, and lead citrate were from SPI chemical companies (Westchester, Pennsylvania, USA).

\section{Preparation of NaSi solutions at different concentrations in potato dextrose broth}

NaSi was added to $100 \mathrm{~mL}$ sterile potato dextrose broth (PDB) (Oxoid, UK) to make solutions at concentrations of $0,20,40,60,80$, and $100 \mathrm{mM}$ and was dissolved completely by shaking. $\mathrm{NaSi}$ solutions were kept in incubator at $28^{\circ} \mathrm{C}$ for $1 \mathrm{~h}$ and the $\mathrm{pHs}$ of the solutions were determined. To 
102

103

104

make control solutions having the same $\mathrm{pH}$ as the $\mathrm{NaSi}$ solutions, a stock solution of $10 \mathrm{M}$ sodium hydroxide was added to distilled water until the corresponding pHs of the NaSi solutions was obtained. The $\mathrm{pH}$ of all solutions was measured using a PHS-3C digital pH-meter (Leici, Shanghai, China).

Determination of the effects of $\mathrm{NaSi}$ and $\mathrm{pH}$ on germination, germ tube elongation, and mycelial growth

Ten $\mu \mathrm{L}$ aliquots of a conidial suspensions $\left(1 \times 10^{6}\right.$ conidia $\left.\mathrm{mL}^{-1}\right)$ were plated on $1 \%$ agar flakes $(5$ $\mathrm{mm}$ in diameter) prepared with: a) different concentrations of $\mathrm{NaSi}(20,40,60,80$, and $100 \mathrm{mM})$; b) different concentrations of $\mathrm{NaOH}$, corresponding to each of the different $\mathrm{pHs}$ of the $\mathrm{NaSi}$; and c) sterile distilled water as a control respectively according to Li et al. (2012). Conidial germination and germ tube length were assessed by observing approximately 200 conidia per treatment under a light microscope after $15 \mathrm{~h}$ of incubation at $28^{\circ} \mathrm{C}$. Conidia were considered germinated if the germ tube was equal to or greater than the diameter of the conidia. Germinated conidia were expressed as percentage of the total number of evaluated conidia. Germ tube length was measured with an ocular micrometer. There were three replicates for each treatment, and the experiment was repeated.

Mycelial growth was assayed according to Yao and Tian (2005). Briefly, mycelial disks (5 mm in diameter) from two-week-old cultures were placed in the center of $90 \mathrm{~mm}$ Petri dishes containing 20 $\mathrm{mL}$ of PDA prepared with: a) different concentrations of $\mathrm{NaSi}(20,40,60,80$, and $100 \mathrm{mM})$; b) different concentrations of $\mathrm{NaOH}$, corresponding to each of the different $\mathrm{pHs}$ of the $\mathrm{NaSi}$ solutions; and c) sterile distilled water as a control. The mycelial growth was determined by measuring colony diameter after $5 \mathrm{~d}$ at $28^{\circ} \mathrm{C}$. Each treatment contained three replicates and the entire experiment was repeated.

\section{Determination of the effects of conidia pretreated with $\mathrm{NaSi}$ and $\mathrm{pH}$ on lesion diameter in}

\section{inoculated apples}

The conidial suspensions $\left(1 \times 10^{6}\right.$ conidia $\left.\mathrm{mL}^{-1}\right)$ of $T$. roseum were prepared with: a) different concentrations of $\mathrm{NaSi}(20,40,60,80$, and $100 \mathrm{mM}), \mathrm{b})$ different concentrations of $\mathrm{NaOH}$, corresponding to each of the different $\mathrm{pHs}$ of the NaSi solutions; and c) sterile distilled water as a control. Then the suspensions were shaken at $200 \mathrm{rpm}$ for 3,6 , and $9 \mathrm{~h}$ at $28^{\circ} \mathrm{C}$. Four wounds $(3 \mathrm{~mm}$ deep and $3 \mathrm{~mm}$ wide) were made with a sterile nail on the equator of each surface-sterilized apple fruit, and $20 \mu \mathrm{L}$ of pretreated conidial suspensions was inoculated into each wound. Inoculated apples were 
131 then stored in low density polyethylene bags at room temperature $\left(20^{\circ} \mathrm{C} \pm 2^{\circ} \mathrm{C}\right)$ with a relative humidity

$132(\mathrm{RH})$ of $75-80 \%$ for 15 days. Lesion diameters of inoculated fruit were then determined in two

133 directions and averaged. Each treatment contained three replicates with 10 fruits per replicate. The

134 experiment was conducted three times.

135 Determination of effects of $\mathrm{NaSi}$ and $\mathbf{p H}$ on conidial plasma membrane integrity

136 A modification of the method by Avis et al. (2009) was used. Briefly, aliquots of $100 \mu \mathrm{L}$ of

137 conidial suspensions $\left(1 \times 10^{7}\right.$ conidia $\left.\mathrm{mL}^{-1}\right)$ were transferred to a $2 \mathrm{~mL}$ sterile Eppendorf tube and

138 centrifuged at $8000 \times \mathrm{g}$ for $5 \mathrm{~min}$. The supernatant was decanted and replaced with three different

139 solutions: a) $1 \mathrm{~mL}$ of $100 \mathrm{mM} \mathrm{NaSi}$; b) $1 \mathrm{~mL}$ of $\mathrm{NaOH}$ solution with $\mathrm{pH}$ of 12.6 ; and c) $1 \mathrm{~mL}$ of sterile

140 distilled water. Conidial suspensions were shaken at $200 \mathrm{rpm}$ at $28^{\circ} \mathrm{C}$ for $0,3,6$, and $9 \mathrm{~h}$, collected by

141 centrifugation at $8,000 \times \mathrm{g}$ for $5 \mathrm{~min}$ at $4^{\circ} \mathrm{C}$, then washed with sterile distilled water twice. Propidium

142 iodide (PI, a compound that penetrates damaged membranes) was added to evaluate the integrity of the

143 plasma membrane in the fungi exposed to these three solutions. According to the method of Liu et al.

144 (2007), the conidial suspensions were stained with $10 \mu \mathrm{g} \mathrm{mL}{ }^{-1}$ of PI for $5 \mathrm{~min}$ at $30{ }^{\circ} \mathrm{C}$, then collected

145 by centrifugation, and washed twice with sterile distilled water to remove residual dye. The conidia

146 were observed with a microscope (Zeiss Axioskop 40, Carl Zeiss, Oberkochen, Germany) equipped

147 with an individual fluorescein rhodamine filter set (Zeiss no.15: excitation BP 546/12 nm, emission LP

$148590 \mathrm{~nm}$ ). Three fields of view from each cover slip were chosen randomly and the number of conidia in

149 a bright-field was counted and defined as the total number, and membrane integrity (MI) was

150 calculated according to the formula:

$151 \quad \operatorname{MI}(\%)=[1-($ number of stained conidia/number of total conidia $)] \times 100$.

152 The experiment was repeated.

153 Determination of the effects of $\mathrm{NaSi}$ and $\mathbf{p H}$ on conidial protein and sugar leakage

154 A modification of the method by Avis et al. (2009) was used. Briefly, $100 \mu \mathrm{L}$ of each conidial

155 suspension $\left(1 \times 10^{7}\right.$ conidia $\left.\mathrm{mL}^{-1}\right)$ was transferred to a $2 \mathrm{~mL}$ sterile eppendorf tube and centrifuged at

$1568000 \times \mathrm{g}$ for $5 \mathrm{~min}$. The supernatant was decanted and replaced with: a) $1 \mathrm{~mL}$ of $\mathrm{NaSi}$ at $0,20,40,60,80$,

157 and $100 \mathrm{mM}$; b) $1 \mathrm{~mL}$ of $\mathrm{NaOH}$ solutions, corresponding to each of the different $\mathrm{pHs}$ of the NaSi

158 solutions; and c) $1 \mathrm{~mL}$ of sterile distilled water as a control. Conidial suspensions were shaken at 200

$159 \mathrm{rpm}$ for either 3,6 , or $9 \mathrm{~h}$ at $28^{\circ} \mathrm{C}$, centrifuged at $8000 \times \mathrm{g}$ for $5 \mathrm{~min}$. Supernatants were collected for

160 determining the leakage of intracellular content by assays of total soluble proteins and total soluble 
161 sugars. The content of soluble protein was determined according to the method by Bradford (1976) and

162 the content of soluble sugar was estimated by the phenol-sulfuric acid method (Dubois et al., 1956).

163 The protein and sugar leakage were expressed as $1 \times 10^{6}$ conidial suspension per mL. Each treatment

164 was replicated three times and the experiment was repeated.

165 Determination of the effects of NaSi and pH on ultrastructure of conidia

166 Conidia treated with either $\mathrm{NaSi}$ at $100 \mathrm{mM}$, the $\mathrm{NaOH}$ solution with $\mathrm{pH}$ of 12.60 , or distilled

167 sterile water (control) for 3, 6, and $9 \mathrm{~h}$ were fixed with a mixture of $3 \%$ glutaraldehyde and $3 \%$ acrolein

168 (pH 7.4) in $0.1 \mathrm{M}$ sodium cacodylate buffer (SCB) under vacuum for $2 \mathrm{~h}$ at $4^{\circ} \mathrm{C}$, and centrifuged

$169\left(16,000 \times \mathrm{g}\right.$ for $5 \mathrm{~min}$ at $\left.4{ }^{\circ} \mathrm{C}\right)$. Fixed conidia were analyzed by the transmission electron microscopy

170 (TEM) according to the method of Avis et al. (Avis et al. 2009). Briefly, gels of 1 to $2 \mathrm{~mm}^{3}$ were

171 prepared by adding 3\% low gelling temperature agarose in SCB to the pellet. After thorough rinsing

172 with $0.1 \mathrm{M} \mathrm{SCB}$, the gels were post-fixed with $2 \%$ osmium tetroxide in $0.1 \mathrm{M} \mathrm{SCB}$ for $1 \mathrm{~h}$ at $20{ }^{\circ} \mathrm{C}$,

173 dehydrated using a series of increasing ethanol concentrations, and embedded in Epon 812. Ultrathin

174 sections were obtained using a diamond knife and stained by soaking in $2 \%$ uranyl acetate for 15 min,

175 and then post-stained in lead citrate for $1 \mathrm{~min}$. Structure alterations in the conidia were analyzed using

176 an electron microscope (JEM-1230, Japan) operating at 80kV. For each treatment, the test was repeated

177 twice and at least two blocks were examined for each replicate.

178 Statistical analysis

179 All statistical analyses were performed using SPSS version 17.0 (SPSS, Inc., Chicago, IL).

180 Data from assays of plasma membrane integrity were compared in independent-samples $t$-test. Others

181 were analyzed by one-way ANOVA. Mean separations were performed by Duncan's multiple range

182 tests. Differences at $P<0.05$ were considered to be significant.

\section{Results}

184 The pHs of NaSi solution at different concentrations in different solvents

185 The $\mathrm{pH}$ value of NaSi solutions at different concentrations of 20, 40, 60, 80, and $100 \mathrm{mM}$ in

186 PDB changed between 10.4 and 12.3. However, the $\mathrm{pH}$ value of NaSi solutions at the different 
187

188

190 concentrations in sterile distilled water changed between 12.0 and 12.6 in sterile (Table 1). The $\mathrm{pH}$ of

$\mathrm{NaSi}$ in the PDB was slightly lower than in sterile distilled water.

NaSi solutions have greater effects than $\mathrm{pH}$ on germination, germ tube elongation and mycelial growth:

The conidial germination and germ tube elongation were significantly inhibited by the NaSi solution at different concentrations and $\mathrm{NaOH}$ solutions. However, $\mathrm{NaSi}$ was more effective under higher $\mathrm{NaSi}$ concentrations than $\mathrm{NaOH}$ only solutions (Fig.1A, B). The conidial germination and germ tube elongation in NaSi reduced by $89.7 \%$ and $86.4 \%$, respectively, when compared with the $\mathrm{NaOH} \mathrm{pH}$ solution of 12.6. The conidial germination and germ tube elongation in $\mathrm{NaSi}$ at $100 \mathrm{mM}$ were reduced by $94 \%$ and $90.8 \%$, respectively, when compared with the control of sterile distilled water.

Treatments with $\mathrm{NaSi}$ at all concentrations and $\mathrm{NaOH}$ solutions inhibited colony diameter.

However, differences were observed between $\mathrm{NaSi}$ and $\mathrm{NaOH}$ treatments: the colony diameter of the $\mathrm{NaOH}$ treatment at $\mathrm{pH} 10.44$ was reduced greater than that $\mathrm{NaSi}$ at $20 \mathrm{mM}$ (Fig. 1C). However, when NaSi concentration was more than $40 \mathrm{mM}$, the inhibition effect on colony diameter was significantly greater $(\mathrm{P}<0.05)$ than those of $\mathrm{NaOH}$ solutions. For example, $\mathrm{NaSi}$ at $80 \mathrm{mM}$ and the $\mathrm{NaOH} \mathrm{pH}$ solution of 11.9 decreased colony diameter by $83 \%$ and $68 \%$, respectively, compared with the control; the effect of $\mathrm{NaSi}$ on colony diameter was 1.9 times greater than the $\mathrm{NaOH}$. The colony diameter was completely inhibited by $\mathrm{NaSi}$ at $100 \mathrm{mM}$.

\section{Pretreated conidia with NaSi has significant effects on lesion diameter in inoculated apples}

$$
\text { The lesion diameters in inoculated apples with NaSi-treatment conidia at 60, } 80 \text { and } 100 \mathrm{mM} \text { were }
$$

significantly reduced compared with the $\mathrm{NaOH}$ treatment and the control. There was no significant 
difference among NaSi treatment at 20, $40 \mathrm{mM}, \mathrm{NaOH}$ treatments and the control (Fig. 2). The lesion

The NaSi concentration at $100 \mathrm{mM}$ with an incubation time of $3 \mathrm{~h}$, resulted in lesion diameters which solution $\mathrm{pH}$ of 12.6. Moreover, the lesion development was completely inhibited with NaSi-treatment conidia at $80 \mathrm{mM}$ for $9 \mathrm{~h}$ (Fig. 2E), and at $100 \mathrm{mM}$ for $6 \mathrm{~h}$ and $9 \mathrm{~h}$ (Fig. 2F).

NaSi treatment damages plasma membrane integrity of conidia

218 However, the MI of the control conidia remained stable during incubation (Fig. 3B). The MI of conidia

$219 \mathrm{NaSi}$ and $\mathrm{NaOH}$ treatment declined significantly with the increase incubation time. The MI of conidia

$\mathrm{NaOH}$ after $9 \mathrm{~h}$ of treatment. However, dyeing in the control conidia indicated little changes (Fig 3A).

\section{NaSi treatment caused leakage of sugar and protein of conidia}

226 difference in leakage was observed between $\mathrm{NaSi}$ and $\mathrm{pH}$ treatments, and $\mathrm{NaSi}$ was more effective at

227 the higher mM concentrations (Fig. 4A). When NaSi concentration was $100 \mathrm{mM}$, the sugar leakage

228 was 1.6 times and 1.2 times greater than the control and the corresponding $\mathrm{pH}$, respectively, after $9 \mathrm{~h}$ of 
229

230

231

232

234 incubation (Fig.4F). Similar results were observed for NaSi-treatment at 40, 60 and $80 \mathrm{mM}$ (Fig. 4C, D, E). On the other hand, the sugar leakage in NaSi-treatment at $20 \mathrm{mM}$ was significantly lower than the $\mathrm{NaOH}$ treatment $\mathrm{pH}$ of 12.0 (Fig. 4B) $(\mathrm{p}<0.05)$.

Similarly, with the increase in incubation time, the protein leakage of conidia treated with NaSi and $\mathrm{pH}$ increased while the leakage of protein in the control conidia was increased slightly (Fig. 5A).

NaSi treatment caused more severe protein leakage than corresponding $\mathrm{pH}$. Protein leakage increased slowly with the treatment of $\mathrm{NaSi}$ at $3 \mathrm{~h}$ and $6 \mathrm{~h}$, then increased rapidly at $9 \mathrm{~h}$ of incubation. For example, when $\mathrm{NaSi}$ concentration was $100 \mathrm{mM}$, the protein leakage at $9 \mathrm{~h}$ incubation was 1.6 times greater than that at $6 \mathrm{~h}$ of incubation. No significant difference was observed between $3 \mathrm{~h}$ and $6 \mathrm{~h}$ of incubation. On the other hand, protein leakage increased rapidly with the corresponding $\mathrm{pH}$ treatment at $3 \mathrm{~h}$ then increased slowly at $6 \mathrm{~h}$ and $9 \mathrm{~h}$ of incubation. For corresponding $\mathrm{pH}$ of 12.6, the protein leakage after incubation for $6 \mathrm{~h}$ and $9 \mathrm{~h}$ was 1.4 times greater than that incubated at $3 \mathrm{~h}$. No significant difference was observed between $6 \mathrm{~h}$ and $9 \mathrm{~h}$ incubation. The leakage of NaSi-treatment conidia at 100 $\mathrm{mM}$ was 2.9 times and 1.6 times higher than those of the control and the corresponding $\mathrm{pH}$, respectively, after $9 \mathrm{~h}$ of incubation (Fig. 5F).

\section{NaSi treatment causes severe damage on ultrastructure of conidia}

Typical conidial ultrastructure of T. roseum was shown in Figure 6A, B, and C. After $3 \mathrm{~h}$ and $6 \mathrm{~h}$ in sterile distilled water ( $\mathrm{pH}$ 6.4), the conidia generally displayed smooth visible cell wall and cell membrane, integrity of the plasma membrane, organized cytoplasma and visible nuclei and other organs with well-defined envelopes (Fig 6A, B). With prolonged incubation in sterile water (9 h), the thickening of cell wall tissue appeared, although the plasma membrane and cytoplasma remained intact 
250 and organized (Fig 6C). For NaSi treatment at $100 \mathrm{mM}$ and $3 \mathrm{~h}$ incubation, T. roseum conidia showed

251 irregular cell-wall thickening, indistinct organelles and a plasmolysis state (Fig 6D). With prolonged

252 incubation for $6 \mathrm{~h}$, the cell-wall layers were not obvious, the cytoplasm appeared condensed and most

253 conidia were greatly altered and organelles were barely distinguished (Fig 6E). A longer exposure

254 period $(9 \mathrm{~h})$ with $100 \mathrm{mM} \mathrm{NaSi}$ induced a more severe plasmolysis state as revealed by the retraction

255 and/or rupture of the plasma membrane, and disorganization and lysis of the cytoplasm content, as well

256 as extensive fragmentation of the plasma membrane (Fig 6F). For $\mathrm{NaOH}$ treatment at $\mathrm{pH} 12.6$ and $3 \mathrm{~h}$

257 incubation, the conidia showed normal cell-wall, normal cell-membrane and cytoplasm, clearly visible

258 organelles, and was overall similar to the structure of the control (Fig. 7G). With longer incubation

259 time, cell-wall became thickened, a plasmolysis state was clearly observed, the cytoplasm had

260 disintegrated, and organelles appeared degraded (Fig. 7H, I). However, the cell-wall was visible, the

261 membrane was still intact, and no exudates were observed. Overall, treatment with NaSi caused more

262 severe ultrastructural changes to conidia than $\mathrm{pH}$.

\section{Discussion}

264 The results of this study indicate that $\mathrm{NaSi}$ and $\mathrm{pH}$ treatments cause damage to T. roseum but that

265 NaSi treatment caused damages more severe than those of $\mathrm{pH}$ treatments alone (using various $\mathrm{NaOH}$

266 solution as a proxy for $\mathrm{pH}$ ). NaSi was effective in inhibiting conidial germination, germ tube

267 elongation and mycelial growth of T. roseum and there also was a concentration-dependent manner in

268 which NaSi treatment with the $100 \mathrm{mM}$ showed a complete inhibition on germination, germ tube

269 elongation and mycelial growth. Our results were consistent with other findings that NaSi showed more

270 antifungal activity against several postharvest fungal pathogens (Bi et al. 2006; Halasz et al. 2010; Liu 
et al. 2010; Wang et al. 2011). It is well known the $\mathrm{pH}$ values of NaSi solutions rise with the increased

272

273

274

275

276

277

278

279

280

concentrations, therefore it was proposed that the effect of inhibition of $\mathrm{NaSi}$ was due to the increase in

pH (Guo et al. 2007; Liu et al. 2010). In the present study, we found that the $\mathrm{NaOH}$ solution could also

inhibit conidial germination, germ tube elongation and mycelial growth. However, the inhibitory effect

showed little change within the range tested of $\mathrm{NaOH}$ solutions $\mathrm{pHs}$. Thus, the higher concentrations of

$\mathrm{NaSi}$ demonstrated a much stronger inhibitory effect than those of the $\mathrm{NaOH}$. To our knowledge, this is

the first study contrasting the effect between $\mathrm{NaSi}$ and $\mathrm{NaOH}$ treatment on conidial germination, germ

tube elongation and mycelial growth. $\mathrm{NaSi}$ is a base salt and aqueous solutions of $\mathrm{NaSi}$ dissociate into

$\mathrm{Na}^{+}$and silicate anions at $\mathrm{pH}>11$ (Halasz et al. 2010). According to our results, we can hypothesize

that the silicate anions probably played a more important role in inhibition than the hydroxide ions.

In vivo results suggested that the pathogenicity of $\mathrm{NaSi}$-treated conidia decreased, while no

evidence for change in pathogenicity was found for the $\mathrm{NaOH}$ treatment compared with the control.

Although, in vitro, $\mathrm{NaOH} \mathrm{pH}$ solution could inhibit the conidial germination, germ tube elongation and

mycelial growth, the germination in $\mathrm{NaOH}-$ treated conidia did not affect fungal growth when

inoculated on the apple host. Apple flesh is acidic and watery, which could neutralize the hydroxide

ions and restore the osmotic pressure around the $\mathrm{NaOH}$-treated conidia. It is possible that the

germination of $\mathrm{NaOH}$ treated conidia was only delayed and reversed in the right environment. The

pathogenicity of NaSi-treated conidia decreased markedly with the increased time when $\mathrm{NaSi}$ was

more than $40 \mathrm{mM}$. The NaSi-treated conidia at $100 \mathrm{mM}$ for $6 \mathrm{~h}$ and $9 \mathrm{~h}$ lost the pathogenicity

completely. It is possible the conidia were irreversible damaged or dead under this conditions. Our 
291 previous results also confirmed the viability of conidia treated with NaSi rapidly decreased (Zhao et al.

292

2015).

The plasma membrane plays a vital role in maintaining a homeostatic environment, exchanging

materials, and transferring energy and information in the cell. Liu et al. (2010) reported antifungal

activity of silicon was attributed to the fact that $\mathrm{NaSi}$ treatment resulted in damage of the plasma

membrane, and leakage of proteins and sugars of $P$.digitatum spores. In our experiments, reduced

membrane integrity was observed with NaSi-treated and corresponding $\mathrm{pH}$-treated conidia shown by PI

staining and determination of the leakage of cytoplasmic materials; these results confirmed that release

of intracellular components is characteristic of $\mathrm{NaSi}$ antifungal effects. Conidial ultrastructural changes

by $\mathrm{NaSi}$ and $\mathrm{NaOH}$ treatment were observed by TEM. Results also confirmed that $\mathrm{NaSi}$ induced even

greater damage than the $\mathrm{NaOH}$ treatment. Longer exposure periods to $\mathrm{NaSi}$ caused rupture of the

plasma membrane, caused disorganization and lysis of the cytoplasm content, and extensive

fragmentation of the plasma membrane, as well as exudates. Similar results have been recently reported

by Qin (2010), who suggested that borate disrupted the cell membrane of $B$. cinerea, eventually leading

to leakage of cytoplasmic materials and the death of the fungal pathogen. Shi et al. $(2011 ; 2012)$ found

that borate altered the ultrastructure of Colletotrichum gloeosporioides conidia, leading to

disintegration of the cytoplasm and degradation of mitochondria. Avis et al. (2009) documented

membrane retraction, undulation, and invagination, loss of membrane integrity, cytoplasmic leakage,

and cell rupture in Fusarium sambucinum after exposure to $\mathrm{AlCl}_{3}$ and $\mathrm{Na}_{2} \mathrm{~S}_{2} \mathrm{O}_{5}$. In $\mathrm{NaOH}$ treatment,

the membrane was still intact and no substances were exuded, although disorganized cytoplasm and

organelles and a plasmolysis state were observed. It has been reported that ambient $\mathrm{pH}$ inhibits growth 
312 of microorganisms by affecting enzyme activities, nutrient availability and the proton gradient across

313 the plasma membrane, as well as cell wall remodeling (Pia Schmidt et al. 2008).

314 In the present research, the $\mathrm{pH}$ of $\mathrm{NaSi}$ from $20 \mathrm{mM}$ to $100 \mathrm{mM}$ in aqueous solution only changed

315 from 12.0 to $12.6 . \mathrm{NaSi}$ is the salt of a very weak acid, so $\left[\mathrm{H}^{+}\right]=([$acid $] /[\mathrm{salt}]) * \mathrm{Kacid}$, and does not

316 change much when the solution is diluted (Iler, 1979); thus, NaSi is a characteristic buffer solution.

$317 \mathrm{NaOH}$ solutions have the same $\mathrm{pH}$ as the NaSi solutions. We have assumed the mechanism of the

318 antifungal activity of $\mathrm{NaSi}$ was likely caused by the silicate anions. However, the reasons for the

319 inhibition of conidial germination are still not well understood. Although our findings showed that the

320 plasma membrane was greatly damaged by NaSi treatment, the mechanism behind plasma membrane

321 damage appeared to be complex. There are several reasons for that. On the one hand, NaSi affects

322 lipoxygenase (LOX) activity, which is the key enzyme in the fatty acid metabolism and catalyzes

323 polyunsaturated fatty containing a cis-1,4-pentadiene structure (linoleic acid, linolenic acid) to produce

324 hydrogen-peroxide. This led to cell wall thickening (O’Brien et al. 2012) and activates membrane lipid

325 peroxidation to produce a series of free radicals such as ROO, RO. These radicals will eventually

326 damage cell membrane structure (Reverberi et al. 2007). On the other hand, salt stress could induce

327 plant oxidative stress and antioxidant defense (Mandhania et al. 2006; Rodrıguez-Rosales et al. 1999;

328 Shi et al. 2007). So, we have deduced that NaSi may be a stress factor to induce fungal oxidative stress

329 and cause the impairment of intracellular redox status, as a result of an increase in generation of

330 reactive oxygen (ROS) beyond the cellular capacity to neutralize, which could lead to a hyperoxidation

331 state (Heller and Tudzynski 2011). Higher ROS is responsible for oxidation of proteins, lipids, and

332 nucleic acids and may cause cell death (Gessler et al. 2007). We also found that the application of 
333 exogenous antioxidants, such as ascorbic acid and reduced glutathione, increased the viability of

334 NaSi-treated conidia (data not shown). Thus the mechanism of membrane damage of NaSi was mainly

335 related to the higher ROS. But further research should focus on the relationship between ROS

336 production in T. roseum and NaSi treatment.

In conclusion, we found that $\mathrm{NaSi}$ and $\mathrm{NaOH}$ treatments could cause damage to T. roseum

338 conidia, and NaSi showed more damage than corresponding $\mathrm{pH}$. Although, in vitro, $\mathrm{NaOH}$ could

339 inhibit the conidial germination, germ tube elongation and mycelial growth, in vivo, $\mathrm{NaOH}$ treatment

340 did not reduce the pathogenicity of T. roseum conidia. Moreover, the membrane integrity, the leakage

341 and the structure of NaSi-treated conidia were also changed considerably more than those treated by

$342 \mathrm{NaOH}$. Thus, we speculated that $\mathrm{NaOH}$ delayed the germination of conidia resulting in dormancy

343 while application of NaSi caused the degradation of the organs in the conidia and eventual death.

\section{Acknowledgements}

345 This research was supported by the National Natural Science Foundation of China (31371869)

346 and the National Natural Science Foundation of China(31071835).

\section{$347 \quad$ References}

348 Avis, T., Rioux, D., Simard, M., Michaud, M., and Tweddell, R. 2009. Ultrastructural alterations in

349 Fusarium sambucinum and Heterobasidion annosum treated with aluminum chloride and sodium

350 metabisulfite. Phytopathology 99(2): 167-175.

351 Bi, Y., Tian, S., Guo, Y., Ge, Y., and Qin, G. 2006. Sodium silicate reduces postharvest decay on Hami

352 melons: induced resistance and fungistatic effects. Plant Dis. 90(3): 279-283. 
Bi, Y., Tian, S., Liu, H., Zhao, J., Cao, J., Li, Y., and Zhang, W. 2003. Effect of temperature on chilling

354 injury, decay and quality of Hami melon during storage. Postharvest Biol. Technol. 29(2): 229-232.

355 Bi, Y., Tian, S., Zhao, J., and Ge, Y. 2005. Harpin induces local and systemic resistance against

356 Trichothecium roseum in harvested Hami melons. Postharvest Biol. Technol. 38(2): 183-187.

357 Bradford, M. 1976. A rapid and sensitive method for the quantitation of microgram quantities of

358 protein utilizing the principle of protein-dye binding. Anal. Biochem. 72(1): 248-254.

359 Chérif, M., Benhamou, N., Menzies, J.G., and Bélanger, R. 1992. Silicon induced resistance in

360 cucumber plants against Pythium ultimum. Physiol. Mol. Plant P. 41(6): 411-425.

361 Datnoff, L., Deren, C., and Snyder, G. 1997. Silicon fertilization for disease management of rice in

362 Florida. Crop Prot. 16(6): 525-531.

363 Dubois, M., Gilles, K., Hamilton, J., Rebers, P., and Smith, F. 1956. Colorimetric method for

364 determination of sugars and related substances. Anal. Chem. 28(3): 350-356.

365 Fauteux, F., Chain, F., Belzile, F., Menzies, J.G., and Bélanger, R.R. 2006. The protective role of

366 silicon in the Arabidopsis-powdery mildew pathosystem. PNAS 103(46): 17554-17559.

367 Gessler, N, Aver'yanov, A., and Belozerskaya, T.A. 2007. Reactive oxygen species in regulation of

368 fungal development. Biochemistry 72(10): 1091-1109.

369 Guo, Y., Liu, L., Zhao, J., and Bi, Y. 2007. Use of silicon oxide and sodium silicate for controlling

370 Trichothecium roseum postharvest rot in Chinese cantaloupe (Cucumis melo L.). Int. J. Food Sci. Tech.

$371 \quad$ 42(8): 1012-1018.

372 Halasz, I., Agarwal, M., Li, R., and Miller, N. 2010. What can vibrational spectroscopy tell about the

373 structure of dissolved sodium silicates? Microporous Mesoporous Mater. 135(1-3): 74-81. 
374 Heller, J., and Tudzynski, P. 2011. Reactive oxygen species in phytopathogenic fungi: signaling,

375 development, and disease. Annu. Rev. Phytopathol. 49: 369-390.

376 Hong, C., and Michailides, T. 1997. Prune, plum, and nectarine as hosts of Trichothecium roseum in

377 California orchards. Plant Dis. 81(1): 112-112.

378 Hu, L., Ma, C., Zhang, J., Tan, W., Yang, G., and Zhang, L. 1995. Infection process of pathogenic

379 fungi contributing to mouldy core and core rot of starking apple fruit. Acta Phytopathologica Sinica

380 25(4): 351-356. (in Chinese)

381 Huang, Y., Deverall, B., Tang, W., Wang, W., and Wu, F. 2000. Foliar application of

382 acibenzolar-S-methyl and protection of postharvest rock melons and Hami melons from disease. Eur. J.

383 Plant Pathol. 106(7): 651-656.

384 Iler, R.K. 1979. The chemistry of silica: solubility, polymerization, colloid and surface pro perties, and 385 biochemistry. Wiley.

386 Ishiguro, K. 2001. Review of research in Japan on the roles of silicon in conferring resistance against

387 rice blast. Pp. 277-291. In: Silicon in Agriculture, Studies in Plant Science. 8, L.E. Datnoff, G. H.

388 Snyder, G. H. Korndorfer Eds., Elsevier, The Netherlands. Li, B., Lai, T., Qin, G., and Tian, S. 2009 a.

389 Ambient $\mathrm{pH}$ stress inhibits spore germination of Penicillium expansum by impairing protein synthesis

390 and folding: a proteomic-based study. J. Proteome Res. 9(1): 298-307.

391 Li, Y., Bi, Y., Ge, Y., Sun, X., and Wang, Y. 2009b. Antifungal activity of sodium silicate on

392 Fusarium sulphureum and its effect on dry rot of potato tubers. J. Food Sci. 74(5): M213-M218. 
$55-61$.

Liang, Y., Sun, W., Si, J., and Römheld, V. 2005. Effects of foliar - and root - applied silicon on the

Liu, J., Tian, S., Meng, X., and Xu, Y. 2007. Effects of chitosan on control of postharvest diseases and

400 physiological responses of tomato fruit. Postharvest Biol. Technol. 44(3): 300-306.

401 Liu, J., Zong, Y., Qin, G., Li, B., and Tian, S. 2010. Plasma Membrane Damage Contributes to

402 Antifungal Activity of Silicon Against Penicillium digitatum. Current Microbiology 61(4): 274-279.

403 Mandhania, S., Madan, S., and Sawhney, V. 2006. Antioxidant defense mechanism under salt stress in

404 wheat seedlings. Bio. Plantarum 50(2): 227-231.

405 Manteau, S., Abouna, S., Lambert, B., and Legendre, L. 2003. Differential regulation by ambient pH of

406 putative virulence factor secretion by the phytopathogenic fungus Botrytis cinerea. FEMS Microbiol.

407 Ecol. 43(3): 359-366.

408 Moscoso-Ramírez, P., and Palou, L. 2014. Preventive and curative activity of postharvest potassium

409 silicate treatments to control green and blue molds on orange fruit. Eur. J. Plant Pathol. 138(4):

$410 \quad 721-732$.

411 O’Brien, J., Daudi, A., Butt, V., and Bolwell, G. 2012. Reactive oxygen species and their role in plant

412 defence and cell wall metabolism. Planta 236(3): 765-779. 
413 Pia Schmidt, Janet Walker, Laura Selway, David Stead, Zhikang Yin, Brice Enjalbert, Weig, M., and

414 Brown, A.J.P. 2008. Proteomic analysis of the $\mathrm{pH}$ response in the fungal pathogen Candida glabrata.

415 Proteomics(8): 534-544.

416 Qin, G., Zong, Y., Chen, Q., Hua, D., and Tian, S. 2010. Inhibitory effect of boron against Botrytis

417 cinerea on table grapes and its possible mechanisms of action. Int. J. Food Microbiol. 138(1-2):

$418 \quad 145-150$.

419 Qin, G., and Tian, S. 2005. Enhancement of Biocontrol Activity of Cryptococcus laurentii by Silicon

420 and the Possible Mechanisms Involved. Phytopathology 95(1): 69-75.

421 Rémus-Borel, W., Menzies, J.G., and Bélanger, R.R. 2005. Silicon induces antifungal compounds in

422 powdery mildew-infected wheat. Physio. Mol. Plant P. 66(3): 108-115.

423 Reverberi, M., Zjalic, S., Punelli, F., Ricelli, A., Fabbri, A.A., and Fanelli, C. 2007. Apyap1 affects

424 aflatoxin biosynthesis during Aspergillus parasiticus growth in maize seeds. Food Addit. Contam.

425 24(10): 1070-1075.

426 Rodriguez-Rosales, M., Kerkeb, L., Bueno, P., and Donaire, J. 1999. Changes induced by NaCl in lipid

427 content and composition, lipoxygenase, plasma membrane $\mathrm{H}^{+}$-ATPase and antioxidant enzyme

428 activities of tomato ( Lycopersicon esculentum. Mill) calli. Plant Sci. 143(2): 143-150.

429 Serra, R., Braga, A., and Venâncio, A. 2005. Mycotoxin-producing and other fungi isolated from

430 grapes for wine production, with particular emphasis on ochratoxin A. Res. Microbiol. 156(4):

$431 \quad 515-521$.

432 Shi, Q., Ding, F., Wang, X., and Wei, M. 2007. Exogenous nitric oxide protect cucumber roots against

433 oxidative stress induced by salt stress. Plant Physiol. Biochem. 45(8): 542-550. 
434 Shi, X., Li, B., Qin, G., and Tian, S. 2011. Antifungal Activity and Possible Mode of Action of Borate

435 Against Colletotrichum gloeosporioideson Mango. Plant Dis. 95(1): 63-69. Shi, X., Li, B., Qin, G., and

436 Tian, S. 2012. Mechanism of antifungal action of borate against Colletotrichum gloeosporioides related

437 to mitochondrial degradation in spores. Postharvest Biol. Technol. 67: 138-143.

438 Sommer, N., Fortlage, R., and Edwards, D. 2002. THE PATHOGEN. Post Harvest Technology of

439 Horticultural Crops 3311: 197.

440 Tang, Y., Xue, H., Bi, Y., Li, Y., Wang, Y., Zhao, Y., and Shen, K. 2014. A method of analysis for T-2

441 toxin and neosolaniol by UPLC-MS/MS in apple fruit inoculated with Trichothecium roseum. Food

442 Additives \& Contaminants: Part A 480-487.

443 Thomas, J.D., and VanBogelen, R.A. 2000. Experimentalism in proteomics. Trends Biotechnol. 18:

$444 \quad 7-11$.

445 Tripathi, P., and Dubey, N. 2004. Exploitation of natural products as an alternative strategy to control

446 postharvest fungal rotting of fruit and vegetables. Postharvest Biol. Technol. 32(3): 235-245.

447 Ueno, Y. 1980. Trichothecene mycotoxins mycology, chemistry, and toxicology. In Advances in

448 nutritional research. Springer. Pp. 301-353.

449 Wang, Y., Bi, Y., Yin, Y., Gao, X., Li, Y., and Ge, Y. 2011. Antifungal Activity of Sodium Silicate on

450 Trichothecium roseum In Vitro. In Acta Horticulturae. Pp. 1683-1690.

451 Welch Jr, A., Jenkins Jr, S., and Averre, C. 1975. Trichothecium fruit rot on greenhouse tomatoes in

452 North Carolina [Trichothecium roseum, fungus diseases]. Plant Disease Reporter 59.

453 Yao, H., and Tian, S. 2005. Effects of a biocontrol agent and methyl jasmonate on postharvest diseases

454 of peach fruit and the possible mechanisms involved. J. Appl. Microbiol. 98(4): 941-950. 
455 Zhao, G., Niu L., Luo R. Duan W., Zhang R, Bi Y., and Zhang S. 2015. Comparison of Protective

456 Effects of Three Antioxidants on Spore Viability of Trichothecium roseum under Sodium

457 Silicate Stress. Food Science. 36(17): 191-195 (in Chinese). 
Table 1 The $\mathrm{pHs}$ of $\mathrm{NaSi}$ at different concentration in potato dextrose broth (PDB) solution and in sterile

\begin{tabular}{ccccccc}
\multicolumn{7}{c}{ distilled water $( \pm \mathrm{SE})$} \\
\hline $\mathrm{NaSi}(\mathrm{mM})$ & 0 & 20 & 40 & 60 & 80 & 100 \\
\hline $\mathrm{pH}$ in PDB & 7.0 & $10.4 \pm 0.03$ & $11.0 \pm 0.05$ & $11.3 \pm 0.03$ & $11.9 \pm 0.06$ & $12.3 \pm 0.03$ \\
$\mathrm{pH}$ in water & 6.4 & $12.0 \pm 0.01$ & $12.3 \pm 0.02$ & $12.4 \pm 0.01$ & $12.5 \pm 0.02$ & $12.6 \pm 0.02$ \\
\hline
\end{tabular}


Fig. 1 Effect of sodium silicate ( $\mathrm{NaSi}$ ) at different concentrations and $\mathrm{NaOH}$ solutions $\mathrm{pH}$ (adjusted to achieve the proper $\mathrm{pHs}$ found in the NaSi solutions) on conidial germination (A), germ tube length (B), and mycelial growth (C) of $T$. roseum. Treatments followed by different letters are statistically different by the Duncan's multiple range test $(p<0.05)$. Conidial germination and germ tube length were measured microscopically after $15 \mathrm{~h}$ of incubation at 28 oC in agar flake and sterile distilled water as a control (0). Mycelial growth was determined by measuring colony diameter after $5 \mathrm{~d}$ of inoculation incubated at $28^{\circ} \mathrm{C}$ and PDA as a control (0).

Fig.2 Effect of wound-inoculated with sodium silicate (NaSi) -treated and $\mathrm{NaOH}$ solutions $\mathrm{pH}$ (adjusted to achieve the proper pHs found in the NaSi solutions) -treated conidia of T.roseum on pathogenicity in apple fruits. Conidia $(1 \times 106$ conidia $\mathrm{ml}-1)$ were pretreated with $\mathrm{NaSi}$ at 20, 40, 60, 80 and $100 \mathrm{mM}$, and $\mathrm{NaOH}$ solutions for $3 \mathrm{~h}, 6 \mathrm{~h}$ and $9 \mathrm{~h}$ at $28 \mathrm{oC}$, and sterile distilled water as control. Inoculated fruits were stored in low density polyethylene bags at room temperature $\left.\left(20^{\circ} \mathrm{C}\right\} 2{ }^{\circ} \mathrm{C}\right)$ with a relative humidity $(\mathrm{RH})$ of $75-80 \%$ for 15 days. Bars represent standard deviations of the means. Treatments followed by different letters are statistically different according to the Duncan's multiple range test $(p<0.05)$.

Fig.3 Effects of $100 \mathrm{mM}$ sodium silicate ( $\mathrm{NaSi}$ ) and $\mathrm{NaOH}$ solutions $\mathrm{pH}$ of 12.6 on plasma membrane integrity of $T$. roseum conidia. The conidia were treated at $28^{\circ} \mathrm{C}$ with $\mathrm{NaSi}$ at 100 $\mathrm{mM}$ and $\mathrm{NaOH}$ solutions $\mathrm{pH}$ of 12.6 for 3,6 and $9 \mathrm{~h}$, sterile water as the control. A: Microscopy images of $T$. roseum conidia after $9 \mathrm{~h}$ of incubation, B: percentage of plasma membrane integrity of $T$. roseum conidia. Data presented are averages of pooled data. Bars represent standard deviations of the means. PI (propidium iodide), a compound that penetrates damaged membranes was assayed to evaluate the integrity of the plasma membrane in thefungi exposed to the solutions.

Fig.4 Effects of sodium silicate (NaSi) at different concentrations and $\mathrm{NaOH}$ solutions $\mathrm{pH}$ (adjusted to achieve the proper $\mathrm{pHs}$ found in the NaSi solutions) on sugar leakage of $T$. roseum. Conidia were incubated $\mathrm{NaSi}$ at 20,40,60,80 and $100 \mathrm{mM}$ and $\mathrm{NaOH}$ solutions for $3 \mathrm{~h}, 6 \mathrm{~h}$ and $9 \mathrm{~h}$ at $28 \mathrm{OC}$, and sterile distilled water as control. Supernatants were used to assay the sugar leakage. A: Control; B: NaSi at $20 \mathrm{mM}, \mathrm{pH}$ at 12.0; C: NaSi at $40 \mathrm{mM}, \mathrm{pH}$ at12.3; D: NaSi at 60 $\mathrm{mM}, \mathrm{pH}$ at 12.4; E: NaSi at $80 \mathrm{mM}, \mathrm{pH}$ at 12.5; F: NaSi at $100 \mathrm{mM}, \mathrm{pH}$ at 12.6. Bars represent standard deviations of the means. Treatments followed by different letters are statistically different according to the Duncan's multiple range test $(p<0.05)$.

Fig.5 Effects of sodium silicate ( $\mathrm{NaSi}$ ) at different concentrations and $\mathrm{NaOH}$ solutions $\mathrm{pH}$ (adjusted to achieve the proper pHs found in the NaSi solutions) on protein leakage of $T$. roseum conidia. Conidia were incubated $\mathrm{NaSi}$ at 20,40,60, 80 and $100 \mathrm{mM}$ and $\mathrm{NaOH}$ solutions for $3 \mathrm{~h}, 6 \mathrm{~h}$ and $9 \mathrm{~h}$ at $28 \mathrm{oC}$, and sterile distilled water as control. Supernatants were used to assay the protein leakage. A: Control; B: NaSi at $20 \mathrm{mM}, \mathrm{pH}$ at 12.0; C: NaSi at $40 \mathrm{mM}, \mathrm{pH}$ at12.3; D: NaSi at $60 \mathrm{mM}, \mathrm{pH}$ at 12.4; $\mathrm{E}: \mathrm{NaSi}$ at $80 \mathrm{mM}, \mathrm{pH}$ at 12.5; F: NaSi at $100 \mathrm{mM}, \mathrm{pH}$ at 
12.6. Bars represent standard deviations of the means. Treatments followed by different letters are statistically different according to the Duncan's multiple range test $(p<0.05)$. 

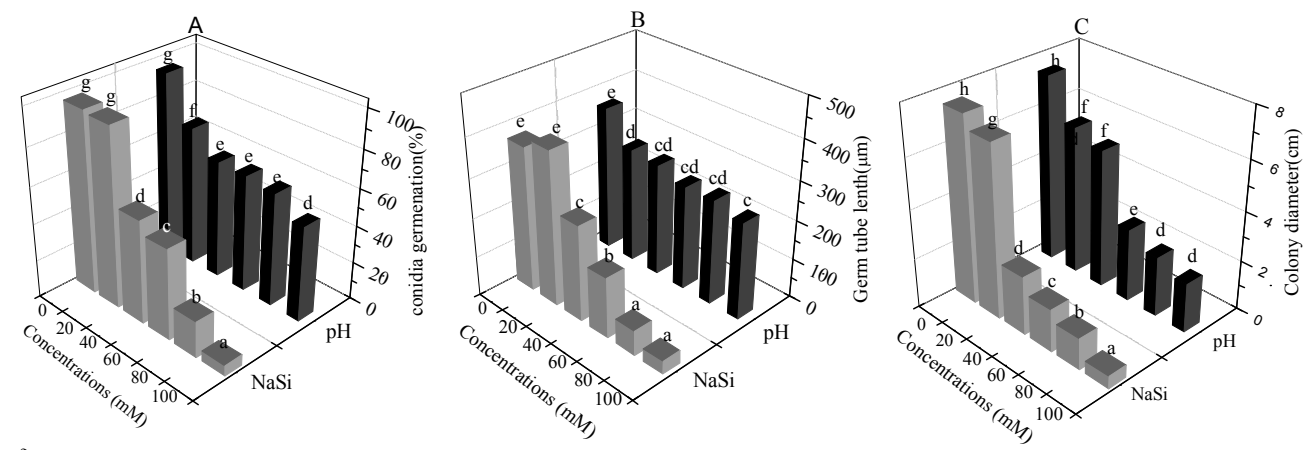

Fig. 1 Effect of sodium silicate $(\mathrm{NaSi})$ at different concentrations and $\mathrm{NaOH}$ solutions $\mathrm{pH}$ (adjusted to achieve the proper $\mathrm{pHs}$ found in the NaSi solutions) on conidial germination (A), germ tube length (B), and mycelial growth (C) of T. roseum. Treatments followed by different letters are statistically different by the Duncan's multiple range test $(\mathrm{p}<0.05)$. Conidial germination and germ tube length were measured microscopically after $15 \mathrm{~h}$ of incubation at $28{ }^{\circ} \mathrm{C}$ in agar flake and sterile distilled water as a control (0). Mycelial growth was determined by measuring colony diameter after $5 \mathrm{~d}$ of inoculation incubated at $28^{\circ} \mathrm{C}$ and PDA as a control (0). 

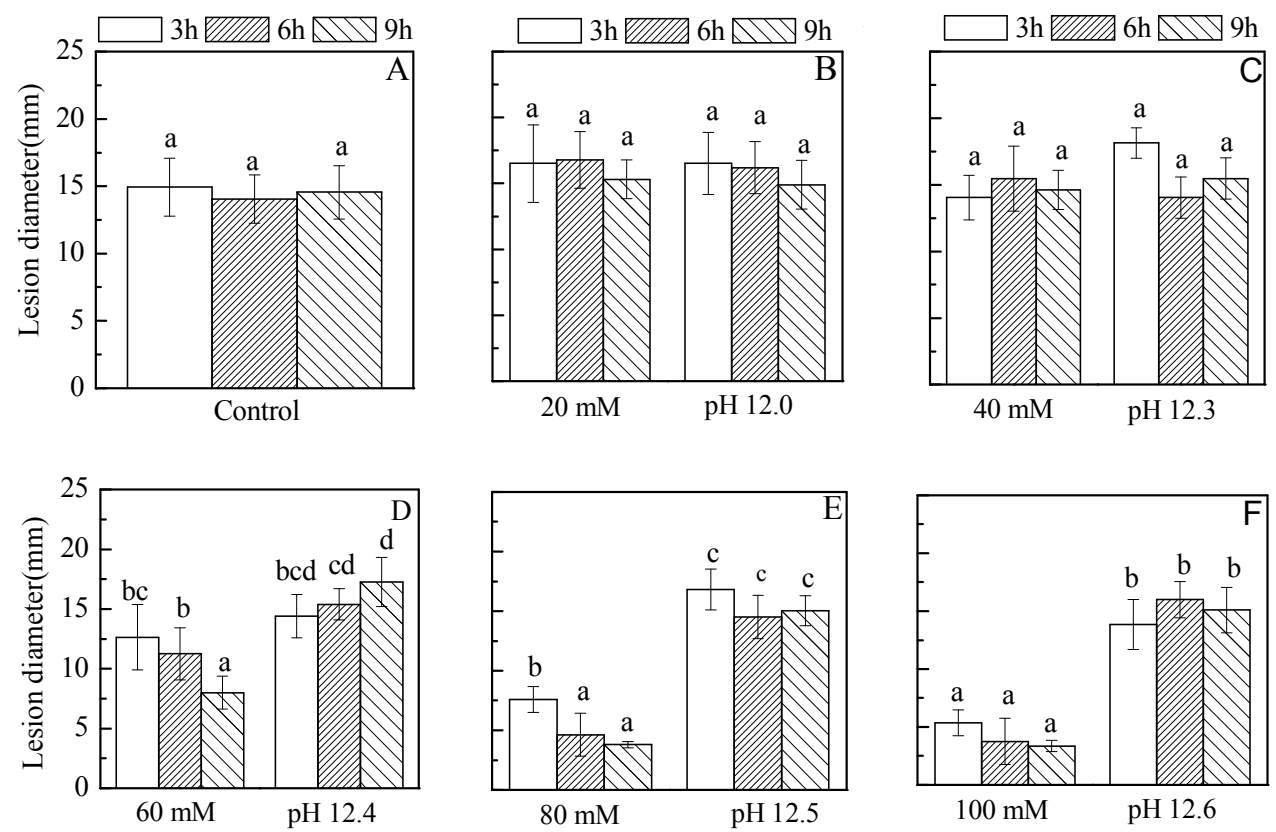

$100 \mathrm{mM}$

Fig.2 Effect of wound-inoculated with sodium silicate (NaSi) -treated and $\mathrm{NaOH}$ solutions pH (adjusted to achieve the proper

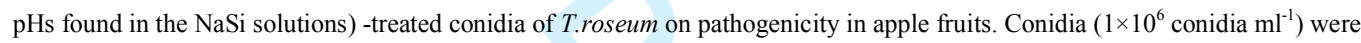
pretreated with $\mathrm{NaSi}$ at 20,40,60, 80 and $100 \mathrm{mM}$, and $\mathrm{NaOH}$ solutions for $3 \mathrm{~h}, 6 \mathrm{~h}$ and $9 \mathrm{~h}$ at $28^{\circ} \mathrm{C}$, and sterile distilled water as control. Inoculated fruits were stored in low density polyethylene bags at room temperature $\left(20^{\circ} \mathrm{C} \pm 2{ }^{\circ} \mathrm{C}\right)$ with a relative humidity $(\mathrm{RH})$ of $75-80 \%$ for 15 days. Bars represent standard deviations of the means. Treatments followed by different letters are statistically different according to the Duncan's multiple range test $(\mathrm{p}<0.05)$. 

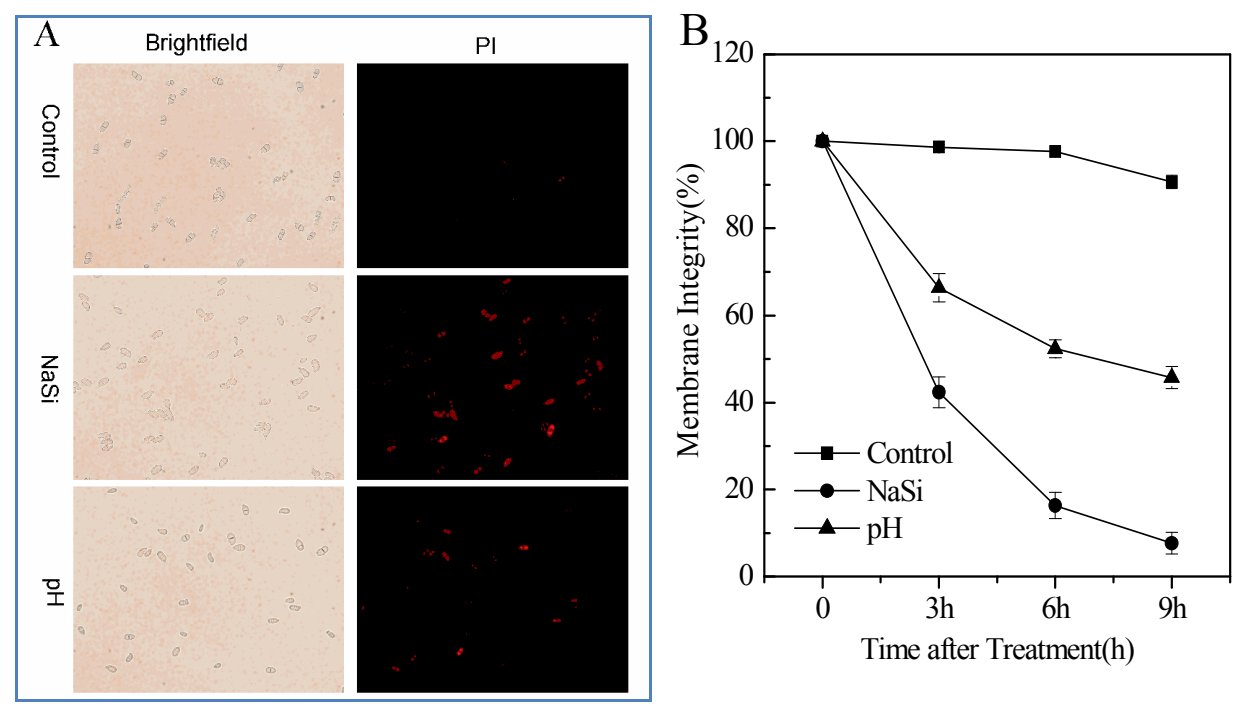

Fig. 3 Effects of $100 \mathrm{mM}$ sodium silicate $(\mathrm{NaSi})$ and $\mathrm{NaOH}$ solutions $\mathrm{pH}$ of 12.6 on plasma membrane integrity of T. roseum conidia. The conidia were treated at $28^{\circ} \mathrm{C}$ with $\mathrm{NaSi}$ at $100 \mathrm{mM}$ and $\mathrm{NaOH}$ solutions $\mathrm{pH}$ of 12.6 for 3,6 and $9 \mathrm{~h}$, sterile water as the control. A: Microscopy images of T. roseum conidia after $9 \mathrm{~h}$ of incubation, B: percentage of plasma membrane integrity of T. roseum conidia. Data presented are averages of pooled data. Bars represent standard deviations of the means. PI (propidium iodide), a compound that penetrates damaged membranes was assayed to evaluate the integrity of the plasma membrane in the fungi exposed to the solutions. 

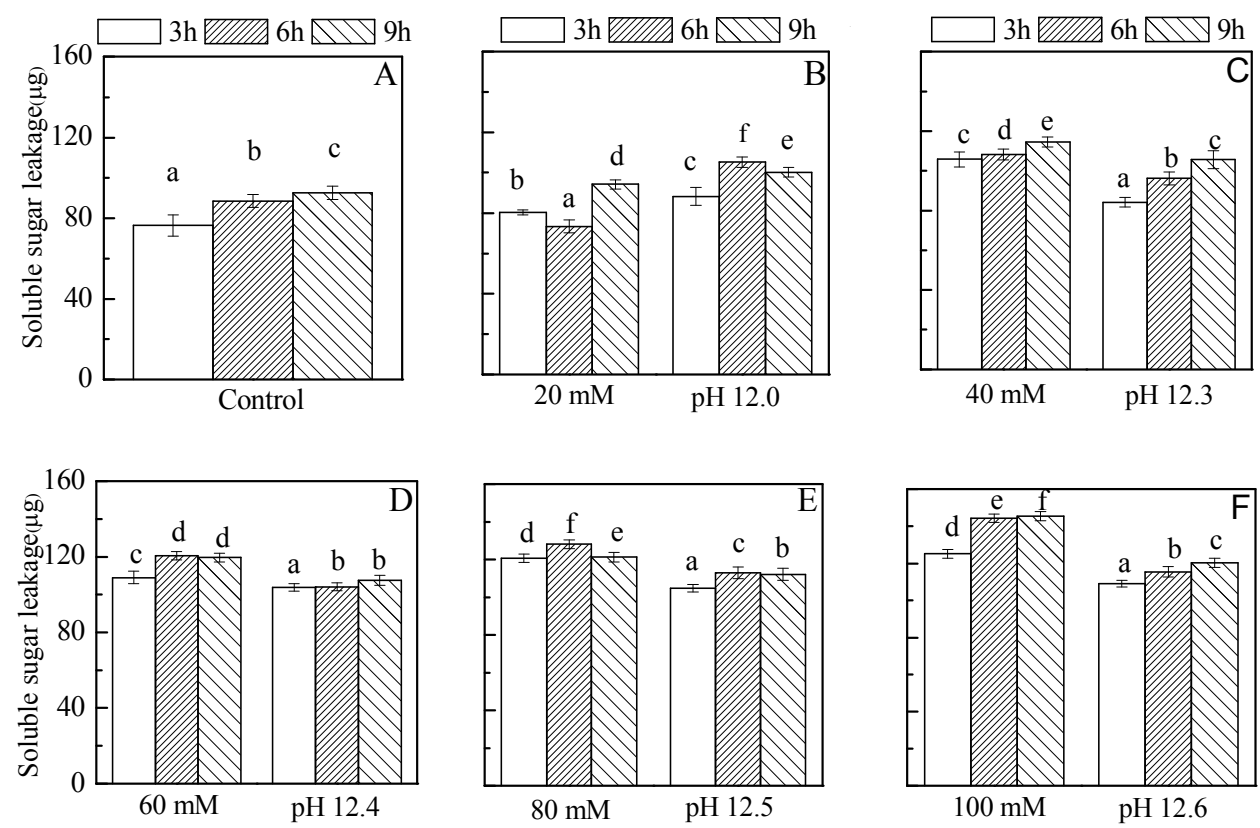

Fig.4 Effects of sodium silicate (NaSi) at different concentrations and $\mathrm{NaOH}$ solutions $\mathrm{pH}$ (adjusted to achieve the proper $\mathrm{pHs}$ found in the NaSi solutions) on sugar leakage of $T$. roseum. Conidia were incubated $\mathrm{NaSi}$ at 20, 40, 60, 80 and $100 \mathrm{mM}$ and $\mathrm{NaOH}$ solutions for $3 \mathrm{~h}, 6 \mathrm{~h}$ and $9 \mathrm{~h}$ at $28^{\circ} \mathrm{C}$, and sterile distilled water as control. Supernatants were used to assay the sugar leakage. A: Control; B: $\mathrm{NaSi}$ at $20 \mathrm{mM}$, pH at 12.0; $\mathrm{C}: \mathrm{NaSi}$ at $40 \mathrm{mM}, \mathrm{pH}$ at12.3; D: $\mathrm{NaSi}$ at $60 \mathrm{mM}, \mathrm{pH}$ at 12.4; E: $\mathrm{NaSi}$ at 80 $\mathrm{mM}, \mathrm{pH}$ at $12.5 ; \mathrm{F}: \mathrm{NaSi}$ at $100 \mathrm{mM}, \mathrm{pH}$ at 12.6. Bars represent standard deviations of the means. Treatments followed by different letters are statistically different according to the Duncan's multiple range test $(\mathrm{p}<0.05)$. 

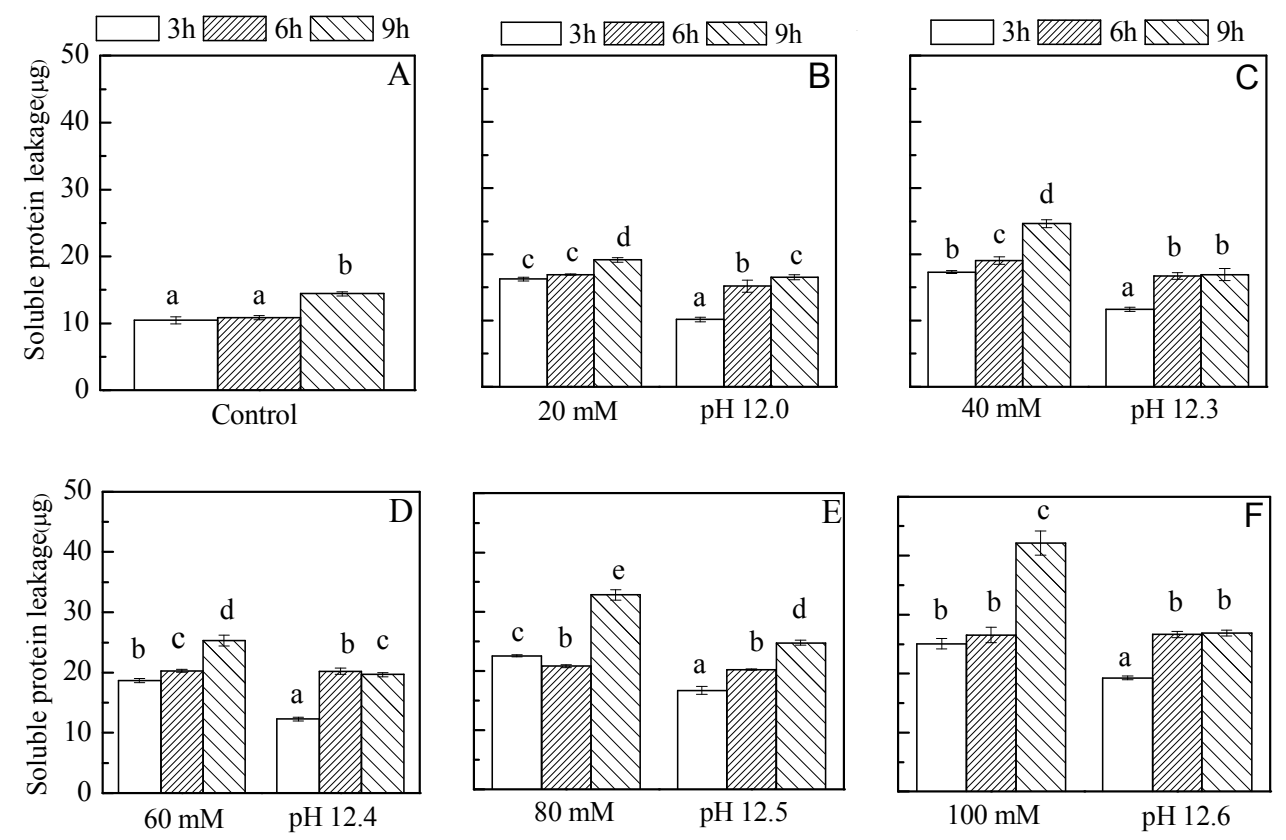

Fig.5 Effects of sodium silicate (NaSi) at different concentrations and $\mathrm{NaOH}$ solutions $\mathrm{pH}$ (adjusted to achieve the proper pHs found in the NaSi solutions) on protein leakage of $T$. roseum conidia. Conidia were incubated $\mathrm{NaSi}$ at 20,40,60, 80 and $100 \mathrm{mM}$ and $\mathrm{NaOH}$ solutions for $3 \mathrm{~h}, 6 \mathrm{~h}$ and $9 \mathrm{~h}$ at $28^{\circ} \mathrm{C}$, and sterile distilled water as control. Supernatants were used to assay the protein leakage. A: Control; B: $\mathrm{NaSi}$ at $20 \mathrm{mM}, \mathrm{pH}$ at 12.0; C: NaSi at $40 \mathrm{mM}, \mathrm{pH}$ at12.3; D: $\mathrm{NaSi}$ at $60 \mathrm{mM}, \mathrm{pH}$ at 12.4; E: $\mathrm{NaSi}$ at $80 \mathrm{mM}, \mathrm{pH}$ at 12.5 ; F: NaSi at $100 \mathrm{mM}, \mathrm{pH}$ at 12.6. Bars represent standard deviations of the means. Treatments followed by different letters are statistically different according to the Duncan's multiple range test $(\mathrm{p}<0.05)$. 


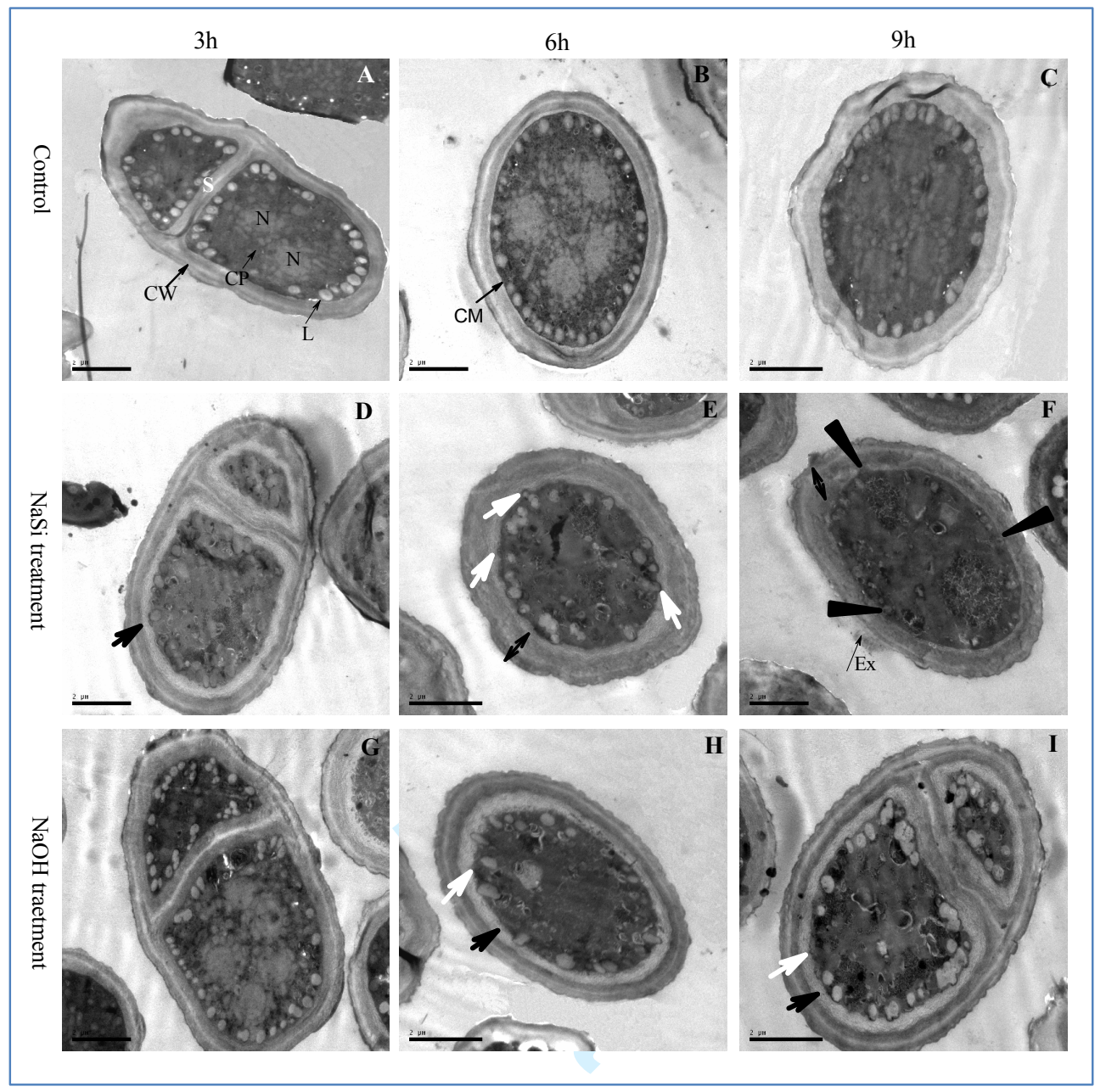

Fig. 6 Effects of $100 \mathrm{mM}$ sodium silicate $(\mathrm{NaSi}), \mathrm{NaOH}$ solution $\mathrm{pH}$ of 12.6 and distilled sterile water (control) on ultrastructure of T. roseum conidia. A to C, After exposure to distilled sterile water for $3 \mathrm{~h}, 6 \mathrm{~h}$, and $9 \mathrm{~h}$, intact cell wall, membrane and other organelles, although the thickening of the cell wall at $9 \mathrm{~h}$. D to F, After exposure to 100 mM NaSi for $3 \mathrm{~h}, 6 \mathrm{~h}$, and $9 \mathrm{~h}$, irregularly thickened cell wall, indistinct organelles, a plasmolysis state (black arrow), degradation of cytoplasm content, cell membrane blebbing (white arrow), leakage of cell wall and cell membrane (double arrow), the cell membrane is fragmented (arrowheads) and excludes were observed. G to I, After exposure to $\mathrm{NaOH}$ solution $\mathrm{pH}$ of 12.6 for $3 \mathrm{~h}, 6 \mathrm{~h}$, and $9 \mathrm{~h}$, irregularly thickened cell wall, indistinct organelles, a plasmolysis state (black arrow), degradation of cytoplasm content, cell membrane blebbing (white arrow), intact cell wall and membrane. $\mathrm{CW}$ : cell wall, $\mathrm{N}$ : cell nucleus, $\mathrm{CP}$ : cytoplasm, $\mathrm{CM}$ : cell membrane, $\mathrm{L}$ : lomasome. EX: excludes. 